\title{
ANALISIS PENGARUH JUMLAH SAHAM BEREDAR, HARGA SAHAM DAN PERSENTASE SAHAM PUBLIK TERHADAP LIKUIDITAS SAHAM PADA PERUSAHAAN MANUFAKTUR SUB SEKTOR INDUSTRI MAKANAN DAN MINUMAN YANG TERDAFTAR DI BURSA EFEK INDONESIA
}

\author{
Winda Paramitha ${ }^{1}$, Iwan Kusuma Negara ${ }^{2}$ \\ ${ }^{\prime}$ Fakultas Ekonomi dan Bisnis Unram, iwanegara@yahoo.com \\ ${ }^{2}$ Fakultas Ekonomi dan Bisnis Unram,windaparamitha23@gmail.com
}

\begin{abstract}
This research aims to analyze the influence of the number of shares outstanding, share price, and percentage of public shares on stock liquidity of food and beverage manufacturing companies listed on Indonesian Stock Exchange in the period of 2010-2015. Type of research used is associative research with quantitative approach. The sampling technique is using purposive sampling. The analytical tool used multiple linear regression analysis where previously tested the classical assumption. The result of this research indicates that partially the number of shares outstanding has positive and significant influence on stock liquidity. While share price, and percentage of public shares partially have positive influence not significant on stock liquidity. The value of adjusted $R$ square shows that the number of shares outstanding, share price, and percentage of public shares are able to explain the stock liquidity equals to 64.8 per cent. Another finding in this research shows that the number of outstanding shares has the most dominant influence on stock liquidity.
\end{abstract}

Keywords: Number of shares outstanding, share price, percentage of public shares, and stock liquidity.

\begin{abstract}
ABSTRAK
Penelitian ini bertujuaan untuk menganalisis pengaruh jumlah saham yang beredar, harga saham dan persentase saham publik terhadap likuiditas saham pada perusahaan makanan dan minuman yang terdaftar di Bursa Efek Indonesia periode 2010-2015. Jenis penelitian yang digunakan adalah penelitian asosiatif dengan pendekatan kuantitatif. Teknik sampling yang digunakan adalah purposive sampling. Alat analisis yang digunakan adalah analisis regresi linier berganda yang sebelumnya dilakukan uji asumsi klasik. Hasil penelitian mengindikasikan bahwa secara parsial jumlah saham yang beredar memiliki pengaruh positif pada likuiditas saham. Sementara harga saham dan persentase saham publik tidak berpengaruh pada likuiditas saham. Nilai dari adjusted $R$ square menunjukan bahwa jumlah saham yang beredar, harga saham dan persentase saham publik mampu menjelaskan likuiditas saham sebesar $64.8 \%$. Temuan lainnya pada penelitian ini adalah jumlah saham yang beredar memiliki pengaruh dominan terhadap likuiditas saham.

Katakunci: Jumlah saham yang beredar, harga saham, persentase saham dan likuiditas saham
\end{abstract}




\section{PENDAHULUAN}

\section{Latar Belakang}

Pasar modal adalah pasar yang memperdagangkan instrumen keuangan jangka panjang, seperti saham dan obligasi serta turunannya (derivatif) misalnya right issue, warrant dan instrumen derivatif lainnya. Secara umum, pasar modal adalah tempat atau sarana bertemunya antara permintaan dan penawaran atas instrumen keuangan jangka panjang, umumnya lebih dari satu tahun (Samsul, 2006 : 43). Menurut UU No. 8 tahun 1995 pasar modal adalah kegiatan yang bersangkutan dengan penawaran umum dan perdagangan efek, perusahaan publik yang berkaitan dengan efek yang diterbitkannya, serta lembaga dan profesi yang berkaitan dengan efek sebagaimana dimaksud dalam Undang-Undang mengenai pasar modal. Dengan demikian, pasar modal memiliki peran penting bagi perusahaan sebagai pihak yang membutuhkan dana dengan menerbitkan instrumen keuangan jangka panjang dan investor sebagai pihak yang ingin berinvestasi di instrumen keuangan tersebut.

Bagi investor, menentukan perusahaan yang tepat untuk berinvestasi di pasar modal bukanlah hal yang mudah. Seorang investor melakukan investasi untuk mendapatkan return maksimal dengan risiko tertentu atau risiko minimal dengan return tertentu, maka sebisa mungkin saham yang dijadikan objek investasi harus memiliki tingkat likuiditas yang baik (Erlinawati dan Mawardi, 2015). Likuiditas saham adalah tingkatan dari setiap sekuritas yang bisa dengan mudah terjual atau dilikuidasi tanpa adanya penurunan nilai (Madura, 2003; Erlinawati dan Mawardi, 2015). Seorang investor akan cenderung menyukai saham-saham dengan likuiditas tinggi karena saat ia membutuhkan dana tunai, saham tersebut dapat dengan mudah dikonversi menjadi kas. Pada kenyataannya tidak semua saham dengan mudah ditransaksikan atau dengan kata lain mengalami kesulitan likuiditas. Dengan tidak likuidnya suatu saham maka kemungkinan akan permintaan saham tersebut akan menurun (Erlinawati dan Mawardi, 2015). Selain itu, saham yang tidak likuid dapat dikenakan delisting atau dikeluarkan dari Bursa Efek.

Memilih saham yang likuid juga perlu memperhatikan jenis sahamnya. Industri manufaktur merupakan industri yang mendominasi perusahaan-perusahaan yang terdaftar di Bursa Efek Indonesia (BEI). Perusahaan dalam industri manufaktur tersebut dikelompokkan menjadi beberapa sub kategori industri. Industri barang konsumsi merupakan salah satu bagian dari perusahaan manufaktur yang ada di Indonesia. Industri barang konsumsi masih menjadi pilihan utama para investor dalam menginvestasikan dana mereka. Hal ini dikarenakan saham-saham dari perusahaanperusahaan dalam industri barang konsumsi yang masih menawarkan potensi kenaikan dan juga industri barang konsumsi terdiri dari 5 sub sektor, salah satunya sub sektor makanan dan minuman.

Sub sektor makanan dan minuman ini merupakan para produsen dari produkproduk kebutuhan mendasar konsumen, yaitu makanan dan minuman. Produk-produk yang dihasilkan tersebut bersifat konsumtif dan disukai orang sehingga para produsen dalam industri ini memiliki tingkat penjualan yang tinggi yang berdampak pula pada pertumbuhan sektor industri ini. Berdasarkan www.bps.go.id, sub sektor industri makanan dan minuman merupakan penopang dalam perusahaan manufaktur. Alasannya adalah sub sektor industri makanan dan minuman memiliki tingkat pertumbuhan yang lebih tinggi dibandingkan sektor industri aneka industri dan sektor industri dasar dan 
kimia. Pada tabel berikut ini disajikan rata-rata pertumbuhan industri manufaktur dari tahun 2010 sampai dengan tahun 2014:

Tabel 1. Laju Pertumbuhan Perusahaan Manufaktur tahun 2010-2014

\begin{tabular}{|c|l|c|}
\hline No & \multicolumn{1}{|c|}{ Kelompok Perusahaan Manufaktur } & $\begin{array}{c}\text { Rata-rata } \\
\text { Pertumbuhan (\%) }\end{array}$ \\
\hline $\boldsymbol{1 .}$ & Sub Sektor Industri Makanan dan Minuman & $\mathbf{8 , 7}$ \\
\hline 2. & Sub Sektor Elektronik & 8,1 \\
\hline 3. & Sub Sektor Industri Logam dan Sejenisnya & 7,4 \\
\hline 4. & Sub Sektor Industri Tekstil dan Garmen & 5,2 \\
\hline 5. & Sub Sektor Industri Mesin dan Alat Berat & 2,7 \\
\hline 6. & Sub Sektor Industri Plastik & 2,2 \\
\hline
\end{tabular}

Sumber : www.bps.go.id, dalam Pane (2016)

Pada Tabel 1 di atas memperlihatkan sub sektor industri makanan dan minuman berada pada posisi pertama dari laju pertumbuhan perusahaan manufaktur. Sub sektor makanan dan minuman merupakan sub sektor dari industri barang konsumsi. Pada posisi kedua ditempati oleh sub sektor industri elektronik. Industri ini merupakan salah satu sub sektor dari Sektor Aneka Industri. Posisi ketiga adalah sektor industri logam dan sejenisnya. Industri ini merupakan salah satu sub sektor dari Sektor Industri Dasar dan Kimia. Tingginya laju pertumbuhan yang dimiliki Sub sektor industri makanan dan minuman berdampak pada tingginya nilai dan likuiditas saham perusahaan dalam industri tersebut.

Parameter yang sering digunakan untuk mengukur likuiditas suatu saham adalah frekuensi perdagangan saham, total volume perdagangan dan selisih dari harga beli saham dan harga jual saham dibandingkan dengan harga jual saham (Wira, 2013). Otoritas BEI sebagai contoh, menggunakan frekuensi, volume, nilai dan jumlah hari transaksi sebagai ukuran-ukuran likuiditas. Semakin besar frekuensi, volume, nilai dan jumlah hari transaksi dari sebuah saham, maka semakin tinggi likuiditas saham tersebut. Pada penelitian ini pengukuran likuiditas saham menggunakan frekuensi perdagangan saham.

Frekuensi perdagangan adalah berapa kali transaksi jual beli terjadi pada saham yang bersangkutan pada waktu tertentu. Saham yang frekuensi perdagangannya besar diduga dipengaruhi transaksi saham yang sangat aktif, hal ini disebabkan karena banyaknya minat investor. Dengan demikian, frekuensi transaksi perdagangan saham dapat diketahui saham tersebut diminati investor atau tidak.

Sudana dan Intan (2008) menjelaskan bahwa likuiditas saham bersifat kompleks karena banyak faktor yang mempengaruhinya. Tingkat likuiditas di bursa dipengaruhi oleh faktor-faktor tertentu. Fokus penelitian ini pada faktor yang termasuk dalam kebijakan perusahaan untuk memberikan peluang kepada masyarakat luas agar dapat ikut serta dalam memiliki saham perusahaan tersebut. Faktor-faktor yang termasuk dalam kebijakan tersebut adalah penentuan jumlah saham beredar, harga saham dan persentase saham publik.

Peluang yang diberikan perusahaan kepada masyarakat luas dinilai penting karena dapat menarik minat beli investor dan meningkatkan daya beli investor terhadap saham perusahaan sehingga dapat meningkatkan likuiditas saham perusahaan tersebut (Ramli, 2014). Selain untuk menarik minat dan daya beli investor, perusahaan juga dapat menarik dana dari masyarakat untuk memenuhi modal yang dibutuhkan dengan cara melakukan peredaran saham kepada masyarakat luas karena perusahaan yang besar 
biasanya tidak cukup jika harus mengandalkan modal dari pemilik dan kreditor (Mulyaningsih, 2013). Oleh karena itulah kebijakan perusahaan dalam menentukan jumlah saham beredar, harga saham dan persentase saham publik penting untuk diperhatikan di luar dari kinerja dan rasio-rasio keuangan perusahaan lainnya. Hal ini diperkuat oleh Ramli (2014) yang menyatakan bahwa meski perusahaan memiliki kinerja baik, tapi jumlah saham beredarnya kecil, dapat mengakibatkan saham tersebut sulit untuk dimiliki dan akan berpengaruh pada likuiditas saham.

Jumlah saham beredar dipilih karena jumlah saham beredar juga dapat mempengaruhi minat dan daya beli investor. Jumlah saham beredar menentukan berapa banyak saham yang dapat dimiliki oleh para investor. Jumlah saham beredar yang kecil akan sulit mengantisipasi peningkatan minat beli investor, sehingga investor akan beralih ke saham perusahaan lain. Reilly dan Brown (2003) dalam Erlinawati dan Mawardi (2015) juga menyatakan bahwa likuiditas saham bisa ditentukan dari besarnya volume perdagangan saham yang bisa diukur melalui jumlah saham beredar ataupun nilai dari transaksi yang dilakukan. Unsur jumlah saham beredar akan menunjukkan kondisi emiten penerbit saham. Nilai ini memberi sinyal bagi investor terkait prospek investasinya di masa mendatang.

Unsur yang kedua yaitu harga saham di pasar. Menurut Halim (2005) dalam Mubarokah (2011) harga saham adalah ringkasan dari pengaruh simultan dan kompleks dari berbagai macam variabel yang berpengaruh, terutama tentang kejadian-kejadian ekonomi bahkan kejadian politik, sosial dan keamanan karena saham merupakan bukti kepemilikan perusahaan yang berupa surat berharga atau efek yang diterbitkan oleh perusahaan yang terdaftar di bursa (go public). Harga saham menjadi salah satu faktor utama yang dilihat oleh setiap calon investor, sebab besarnya harga menentukan daya beli investor dimana bila harga saham tersebut dinilai terlalu tinggi oleh pasar, maka jumlah permintaannya akan berkurang. Sebaliknya, bila pasar menilai bahwa harga saham tersebut terlalu rendah, jumlah permintaannya akan meningkat. Tingginya harga saham akan mengurangi kemampuan para investor untuk membeli harga saham tersebut (Erlinawati dan Mawardi, 2015).

Unsur ketiga adalah persentase saham publik yang merupakan bagian dari saham perusahaan yang dimiliki oleh investor publik di luar internal perusahaan. Tinggi rendahnya persentase saham publik memberi informasi bagi setiap investor terutama berkaitan dengan besarnya return yang akan dia terima jika turut berinvestasi di saham tersebut. Semakin besar proporsi kepemilikan saham oleh publik, maka semakin banyak pihak yang membutuhkan informasi tentang perusahaan sehingga semakin menumbuhkan kepercayaan publik kepada perusahaan tersebut semakin besar (Ramli, 2014). Berikut ini disajikan data rata-rata perkembangan frekuensi perdagangan saham, jumlah saham beredar, harga saham dan persentase saham publik pada perusahaan manufaktur sub sektor makanan dan minuman yang listed di BEI periode 2010-2015 :

Tabel 2. Rata-rata Perkembangan Frekuensi Perdagangan Saham, Jumlah Saham Beredar, Harga Saham dan Persentase Saham Publik Perusahaan Sub Sektor Industri Makanan dan Minuman Periode 2010-2015

\begin{tabular}{|l|r|r|r|r|r|r|}
\hline \multicolumn{1}{|c|}{ Variabel } & \multicolumn{1}{c|}{$\mathbf{2 0 1 0}$} & $\mathbf{2 0 1 1}$ & $\mathbf{2 0 1 2}$ & $\mathbf{2 0 1 3}$ & $\mathbf{2 0 1 4}$ & \multicolumn{1}{c|}{$\mathbf{2 0 1 5}$} \\
\hline $\begin{array}{l}\text { Frekuensi } \\
\text { Perdagangan } \\
\text { Saham (x) }\end{array}$ & 6.383 & 5.422 & 4.946 & 6.746 & 10.250 & 11.412 \\
\hline Jumlah Saham & 2.039 .764 .818 & 2.165 .164 .818 & 2.165 .164 .818 & 2.582 .885 .217 & 2.820 .738 .217 & 2.928 .882 .804 \\
\hline
\end{tabular}

28 | Analisis Pengaruh Jumlah Saham Beredar, Harga Saham.... 


\begin{tabular}{|l|r|r|r|r|r|r|}
\hline \multicolumn{1}{|c|}{ Variabel } & $\mathbf{2 0 1 0}$ & $\mathbf{2 0 1 1}$ & $\mathbf{2 0 1 2}$ & \multicolumn{1}{c|}{$\mathbf{2 0 1 3}$} & \multicolumn{1}{c|}{$\mathbf{2 0 1 4}$} & \multicolumn{1}{c|}{$\mathbf{2 0 1 5}$} \\
\hline $\begin{array}{l}\text { Beredar } \\
\text { (lembar) }\end{array}$ & & & & & & \\
\hline $\begin{array}{l}\text { Harga Saham } \\
\text { (Rp) }\end{array}$ & $42.030,50$ & 50.015 & 103.836 & 505.264 & 45.086 & 6.586 \\
\hline $\begin{array}{l}\text { Persentase } \\
\text { Saham Publik } \\
(\%)\end{array}$ & 26,219 & 28,623 & 29,262 & 29,883 & 29,429 & 29,333 \\
\hline
\end{tabular}

Sumber : Indonesian Stock Exchange (IDX) Periode 2010-2015 (Data Sekunder diolah)

Pada tabel 2 menunjukkan bahwa terjadi perubahan baik peningkatan dan penurunan pada frekuensi perdagangan saham, jumlah saham beredar, harga saham dan persentase saham publik selama periode pengamatan. Peningkatan frekuensi perdagangan saham yang sangat tajam terjadi pada tahun 2014 yaitu sebesar 3.504 kali atau 51,94 persen. Sedangkan penurunan yang sangat tajam terjadi pada tahun 2011 yaitu sebesar 961 kali atau 17,72 persen. Peningkatan dan penurunan ini terjadi karena berbagai faktor termasuk jumlah saham beredar, harga saham dan persentase saham publik.

Pada unsur jumlah saham beredar peningkatan yang sangat tajam terjadi pada tahun 2013 yaitu sebesar 417.720.399 lembar saham atau 19,29 persen. Berdasarkan annual report setiap peusahaan dijelaskan bahwa telah terjadi corporate action yaitu stock split pada perusahaan dengan kode ROTI dan telah dilakukan pembagian saham bonus kepada para pemegang saham oleh perusahaan dengan kode MYOR. Berdasarkan data frekuensi perdagagan saham dan jumlah saham beredar dapat diketahui bahwa pada tahun 2011 terjadi peningkatan jumlah saham beredar tetapi tidak diikuti oleh peningkatan frekuensi perdagangan sahamnya.

Selanjutnya pada unsur harga saham terjadi peningkatan yang sangat tajam pada tahun 2013 yaitu sebesar Rp 401.428,- atau 386,59 persen. Sedangkan penurunan yang sangat tajam terjadi pada tahun 2014 yaitu sebesar Rp 460.178,- atau 102,06 persen. Berdasarkan data frekuensi perdagangan saham dan harga saham dapat diketahui bahwa ada perusahaan yang mengalami peningkatan harga saham diikuti oleh peningkatan frekuensi perdagangan saham dan ada peningkatan harga saham yang tidak diikuti frekuensi perdagangan saham.

Kemudian unsur yang terakhir yaitu persentase saham publik yang mengalami peningkatan dan penurunan yang cukup stabil selama tahun pengamatan. Berdasarkan data frekuensi perdagangan saham dan persentase saham publik dapat diketahui bahwa terjadi peningkatan jumlah saham beredar tetapi tidak diikuti oleh peningkatan frekuensi perdagangan sahamnya seperti pada tahun 2011 dan 2012.

Penelitian tentang faktor-faktor yang mempengaruhi likuiditas saham sudah cukup banyak dilakukan. Namun masih terdapat inkonsistensi antara hasil penelitian yang satu dengan penelitian lainnya. Penelitian yang dilakukan oleh Mulyaningsih (2013) dan Elta (2016) menunjukkan bahwa jumlah saham beredar berpengaruh positif dan signifikan terhadap likuiditas saham. Namun demikian, kedua hasil penelitian tersebut berbeda dengan temuan Erlinawati dan Mawardi (2015) bahwa jumlah saham beredar berpengaruh negatif tidak signifikan terhadap likuiditas saham.

Penelitian Widowati (2013) menemukan bahwa harga saham berpengaruh positif dan signifikan terhadap likuiditas saham. Temuan ini tidak sejalan dengan temuan Sediati (2008) dan Hadya (2013) yang menunjukkan bahwa harga saham berpengaruh positif tetapi tidak signifikan terhadap likuiditas saham. Temuan tersebut 
juga berlawanan dengan hasil penelitian Mubarokah (2011) dan Rahma (2015) yang menyatakan bahwa harga saham berpengaruh negatif dan signifikan terhadap likuiditas saham.

Hasil penelitian Erlinawati dan Mawardi (2013) menunjukkan bahwa persentase saham publik berpengaruh positif dan signifikan terhadap likuiditas saham. Hasil penelitian tersebut berbeda/inkonsisten dengan hasil penelitian Ramli (2014) yang menyatakan bahwa persentase kepemilikan publik tidak berpengaruh signifikan terhadap likuiditas saham. Oleh karena itu, sebuah penelitian empirik lebih lanjut dibutuhkan untuk meneliti inkonsistensi ini.

\section{Perumusan Masalah}

Berdasarkan uraian pada latar belakang, maka dapat dirumuskan permasalahan yaitu apakah jumlah saham beredar, harga saham dan persentase saham publik berpengaruh terhadap likuiditas saham perusahaan manufaktur sub sektor industri makanan dan minuman yang terdaftar di BEI periode 2010-2015?

\section{Tujuan Penelitian}

Tujuan dalam penelitian ini adalah untuk menganalisis pengaruh jumlah saham beredar, harga saham dan persentase saham publik terhadap likuiditas saham perusahaan manufaktur sub sektor makanan dan minuman yang terdaftar di BEI periode 2010-2015.

\section{Penelitian Terdahulu}

\section{LANDASAN TEORI}

Penelitian Erlinawati dan Mawardi (2015) dengan judul Pengaruh Jumlah Saham Beredar, Harga Saham dan Persentase Saham Publik Terhadap Likuiditas Saham Perusahaan yang Listing di JII Periode 2013. Tujuan dari penelitian ini adalah untuk mengetahui pengaruh jumlah saham beredar, harga saham dan persentase saham publik secara parsial dan simultan terhadap likuiditas saham perusahaan yang listing di JII periode 2013. Variabel independen dalam penelitian ini adalah jumlah saham beredar, harga saham dan persentase saham publik. Sedangkan variabel dependennya adalah likuiditas saham dengan proxy volume perdagangan saham. Metode pengumpulan data yang digunakan adalah sensus. Teknik analisis yang digunakan adalah regresi linier berganda. Hasil penelitian menunjukkan bahwa secara parsial, harga saham dan persentase saham publik berpengaruh signifikan terhadap likuiditas saham. Sedangkan variabel jumlah saham beredar berpengaruh tidak signifikan terhadap likuiditas saham. Secara simultan jumlah saham beredar, harga saham dan persentase saham publik berpengaruh signifikan terhadap likuiditas saham.

Elta (2016) yang berjudul Pengaruh Jumlah Saham Beredar, IFR, Tingkat Pengungkapan Informasi Website dan Harga Saham Penutupan Terhadap Frekuensi Perdagangan Saham Perusahaan yang Terdapat pada Indeks Kompas 100 Februari-Juli 2015. Variabel independen pada penelitian ini adalah jumlah saham beredar, IFR, tingkat pengungkapan informasi website dan harga saham. Sedangkan variabel dependennya adalah frekuensi perdagangan saham. Penelitian ini bertujuan untuk mengetahui pengaruh jumlah saham beredar, IFR, tingkat pengungkapan informasi website dan harga saham penutupan terhadap frekuensi perdagangan saham perusahaan. Data yang digunakan dalam penelitian ini merupakan data cross section. Teknik pengambilan sampel dilakukan dengan metode purposive sampling. Teknik 
analisis yang digunakan adalah analisis regresi linier berganda. Hasil dari penelitian ini menunjukkan bahwa jumlah saham beredar, IFR, tingkat pengungkapan informasi website dan harga saham berpengaruh signifikan terhadap frekuensi perdagangan saham. Secara parsial hanya jumlah saham beredar dan harga saham yang berpengaruh positif dan signifikan terhadap frekuensi perdagangan saham. Sedangkan IFR dan tingkat pengungkapan informasi website tidak berpengaruh signifikan terhadap frekuensi perdagangan saham.

Hadya (2013) yang berjudul Pengaruh Harga dan Risiko Saham Terhadap Likuiditas Saham pada Perusahaan-perusahaan yang Terdaftar di BEI. Penelitian ini bertujuan untuk mengetahui pengaruh masing-masing variabel bebas yaitu harga saham dan risiko saham dalam mempengaruhi variabel terikat yaitu likuiditas saham yang menggunakan proksi volume perdagangan saham. Jenis penelitian ini adalah penelitian kausif. Adapun teknik analisis yang digunakan untuk menguji harga saham dan varians terhadap likuiditas saham adalah teknik analisis induktif. Teknik Sampling yang digunakan yaitu purposive sampling. Hasil dari penelitian ini menunjukkan bahwa risiko saham berpengaruh positif dan signifikan terhadap likuiditas saham. Sedangkan harga saham memiliki pengaruh positif tidak signifikan terhadap likuiditas saham.

Mubarokah (2011) yang berjudul Analisis Pengaruh Harga Saham, Return Saham dan Volume Perdagangan Terhadap Likuiditas Saham Pada Perusahaan Go Public yang Melakukan Stock Split di BEI. Variabel independen dari penelitian ini adalah harga saham, return saham, dan volume perdagangan saham. Sedangkan variabel dependennya adalah likuiditas saham dengan menggunakan proksi bid ask spread. Tujuan dari penelitian ini adalah untuk menganalisis pengaruh harga saham, return saham dan volume perdagangan terhadap likuiditas saham. Teknik Sampling yang digunakan yaitu purposive sampling. Data dianalisis dengan metode uji asumsi klasik, regresi linier berganda. Uji beda t-test, Uji $F$ dan Uji t. Hasil penelitian menunjukkan bahwa terdapat pengaruh yang negatif dan signifikan antara harga saham terhadap likuiditas saham sebelum stock split.

Mulyaningsih (2013) melakukan penelitian dengan judul Analisis Pengaruh Jumlah Saham Beredar, Arus Kas dan Rasio Profitabilitas Terhadap Likuiditas Saham Pada Perusahaan Otomotif yang Terdaftar di Bursa Efek Indonesia. Variabel independen dalam penelitian ini adalah jumlah saham beredar, arus kas dan rasio profitabilitas. Sedangkan variabel dependennya adalah likuiditas saham dengan menggunakan proksi volume perdagangan saham. Adapun tujuan dari penelitian yaitu untuk mengetahui pengaruh jumlah saham beredar, arus kas dan rasio profitabilitas terhadap likuiditas saham perusahaan otomotif yang terdaftar di BEI. Teknik Sampling yang digunakan adalah purposive sampling. Penelitian ini menggunakan analisis regresi linier berganda. Hasil dari penelitian ini adalah jumlah saham beredar berpengaruh positif dan signifikan terhadap likuiditas saham. Sedangkan arus kas dan rasio profitabilitas tidak berpengaruh signifikan terhadap likuiditas saham.

Ramli (2014) yang berjudul Faktor-faktor yang Mempengaruhi Tingkat Likuiditas Saham Pada Perusahaan LQ45 yang Listing di BEI. Variabel independen dalam penelitian ini adalah kinerja perusahaan, $P E R, E P S, P B V$, ukuran perusahaan, $N P M$, jumlah saham beredar, persentase kepemilikan publik dan persentase kepemilikan manajerial. Sedangkan variabel dependennya adalah likuiditas saham dengan proksi volume perdagangan saham. Jenis penelitian ini adalah survei (survey research). Penelitian ini bersifat eksplanatory. Pemilihan sampel dalam penelitian 
dilakukan dengan metode purposive sampling. Teknik analisis yang digunakan adalah analisis regresi linier berganda. Hasil dari penelitian ini menunjukkan bahwa kinerja perusahaan, $P E R, E P S, P B V$, ukuran perusahaan, $N P M$ dan persentase kepemilikan manajerial berpengaruh signifikan terhadap tingkat likuiditas saham. Sedangkan jumlah saham beredar dan persentase kepemilikan publik tidak berpengaruh signifikan terhadap tingkat likuiditas saham.

Penelitian Widowati (2013) yang berjudul Pengaruh Harga Saham, Volatilitas Return dan Volume Transaksi Saham Terhadap Likuiditas Saham. Variabel independen dalam penelitian ini adalah harga saham, volatilitas return dan volume transaksi saham. Sedangkan variabel dependennya adalah likuiditas saham dengan menggunakan proksi bid ask spread. Tujuan dari penelitian ini adalah untuk menganalisis pengaruh harga saham, volatilitas return dan volume transaksi terhadap likuiditas saham. Pemilihan sampel dalam penelitian dilakukan dengan metode purposive sampling. Teknik analisis yang digunakan dalam penelitian ini adalah analisis statistik deskriptif. Hasil dari penelitian ini menunjukkan bahwa harga saham berpengaruh positif dan signifikan terhadap likuiditas saham. Sedangkan volatilitas return dan volume transaksi saham tidak berpengaruh signifikan terhadap likuiditas saham.

Rahma (2015) dengan judul Analisis Pengaruh Harga Saham dan Volume Perdagangan Saham Terhadap Likuiditas Saham pada Perusahaan Go Public yang melakukan stock split di Bursa Efek Indonesia. Penelitian ini bertujuan untuk mengetahui pengaruh variabel independen yaitu harga saham dan volume perdagangan saham terhadap variabel dependen yaitu likuiditas saham dengan proksi bid ask spread pada perusahaan yang melakukan stock split. Penelitian ini merupakan jenis penelitian kuantitatif dengan analisis deskriptif. Pengambilan sampel dilakukan dengan teknik purposive sampling. Berdasarkan hasil uji $\mathrm{F}$ diketahui bahwa secara simultan harga saham dan volume perdagangan saham berpengaruh secara signifikan terhadap likuiditas saham. Hasil uji t menunjukkan bahwa harga saham berpengaruh negatif dan signifikan terhadap likuiditas saham. Sedangkan volume perdagangan saham tidak berpengaruh signifikan terhadap likuiditas saham.

Carolina (2014) yang berjudul Analisis Pengaruh Mekanisme Tata Kelola Perusahaan dan Manajemen Laba Terhadap Likuiditas Pasar Saham. Variabel independen dalam penelitian ini adalah komisaris independen dan kepemilikan publik, yang merupakan proksi dari mekanisme tata kelola perusahaan serta manajemen laba. Variabel dependen dalam penelitian ini adalah likuiditas pasar saham. Pengambilan sampel dilakukan dengan menggunakan metode purposive sampling. Teknik analisis data yang digunakan dalam penelitian ini adalah statistik deskriptif dan regresi linier berganda. Hasil penelitian menunjukkan bahwa komisaris independen dan manajemen laba tidak berpengaruh secara signifikan terhadap likuiditas pasar saham. Sedangkan kepemilikan publik berpengaruh positif dan signifikan terhadap likuiditas pasar saham.

\section{Likuiditas Saham}

Likuiditas saham adalah tingkatan dari setiap sekuritas yang bisa dengan mudah terjual atau dilikuidasi tanpa adanya penurunan nilai (Madura, 2003; Erlinawati dan Mawardi, 2015). Likuditas saham diukur dari kemampuan suatu aktiva finansial untuk diubah bentuknya menjadi kas atau sebaliknya pada setiap saat tanpa ada kerugian dan mereka menyatakan bahwa likuiditas adalah suatu dimensi utama dari proses alokasi kekayaan investor (Robinson dan Wrightman, 1991; Adriana, 2007). External market 
liquidity as the ability to buy or sell an asset quickly with little price change from a prior transaction assuming no new information (Brown, 2003; Erlinawati dan Mawardi, 2015).

Semakin likuid suatu saham, maka semakin tinggi frekuensi transaksi saham tersebut. Hal ini menunjukkan minat investor untuk memiliki saham tersebut juga tinggi. Dengan demikian, likuiditas merupakan salah satu faktor penting yang perlu diperhatikan investor dalam pengambilan keputusan investasi.

\section{Faktor - Faktor Yang Mempengaruhi Likuiditas Saham}

Menurut Ervendi (2008) dalam Ramli (2014) ada beberapa faktor yang mempengaruhi tingkat likuiditas saham yaitu:

1. Kinerja Perusahaan Emiten

2. Jumlah Saham Beredar

3. Persentase Kepemilikan Publik

4. Persentase Tingkat Kepemilikan Manajerial

5. Price Earning Ratio (PER)

6. Earning Per Share (EPS)

7. Price To Book Value (PBV)

8. Ukuran Perusahaan

9. Net Profit Margin (NPM)

Faktor-faktor lain yang mempengaruhi likuiditas saham (Ang, 1997; Elta, 2015) antara lain adalah:

1. Jumlah saham beredar

2. Faktor fundamental emiten

3. Harga saham

\section{Pengukuran Likuiditas Saham}

Menurut Wira (2013) ada beberapa metode yang digunakan untuk pengukuran tingkat likuiditas saham suatu perusahaan, yaitu:

1. Frekuensi perdagangan, yaitu banyak kali transaksi terjadi di pasar modal.

2. Total volume perdagangan yang diukur dengan jumlah saham yang diperdagangkan dibandingkan dengan jumlah saham yang dikeluarkan oleh perusahaan.

3. Selisih dari harga beli saham dan harga jual saham dibandingkan dengan harga jual saham.

Parameter lain yang sering digunakan untuk mengukur likuiditas suatu saham (Hadya, 2013) adalah sebagai berikut :

1. Volume perdagangan

Merupakan suatu instrumen yang dapat digunakan untuk melihat reaksi pasar modal terhadap informasi melalui parameter volume saham yang diperdagangkan di pasar.

2. Tingkat Spread

Merupakan suatu instrumen yang dapat digunakan untuk melihat reaksi pasar modal terhadap informasi melalui parameter perbedaan atau selisih antara harga tertinggi yang diminta untuk membeli dengan harga terendah yang ditawarkan untuk menjual (Bid-Ask Spread), diukur dengan menggunakan persentase.

3. Information flow (aliran informasi).

4. Jumlah pemegang saham 
5. Jumlah saham yang beredar

6. Transaction cost (besarnya biaya transaksi).

\section{Frekuensi Perdagangan Saham}

Frekuensi perdagangan saham adalah berapa kali transaksi jual beli terjadi pada saham yang bersangkutan pada waktu tertentu. Saham yang frekuensi perdagangannya besar diduga dipengaruhi transaksi saham yang sangat aktif, hal ini disebabkan karena banyaknya minat investor.

\section{Jumlah Saham Beredar}

Jumlah saham beredar merupakan kuantitas saham yang beredar di pasar modal yang dapat ditransaksikan baik itu dijual atau dibeli oleh investor. Pengertian ini sesuai dengan pernyataan oleh Darmadji dan Fakhruddin (2001) dalam Erlinawati dan Mawardi (2015) yang menjelaskan bahwa banyaknya saham beredar di masyarakat memang ditujukan untuk menarik minat investor agar mau melakukan investasi pada saham tersebut.

\section{Harga Saham}

Harga saham adalah harga pasar (market value) yaitu harga yang terbentuk di pasar jual beli saham (Jogiyanto, 2013). Harga saham yang terlalu tinggi dapat mengurangi minat investor untuk berinvestasi sehingga harga saham sulit untuk meningkat lagi. Bila harga saham tersebut dinilai terlalu tinggi oleh pasar, maka jumlah permintaannya akan berkurang. Sebaliknya bila pasar menilai bahwa harga saham tersebut terlalu rendah, jumlah permintaannya akan meningkat. Tingginya harga saham akan mengurangi kemampuan para investor untuk membeli harga saham tersebut. Para pelaku pasar modal khususnya para investor sangat dipengaruhi oleh pergerakan harga saham suatu perusahaan dan informasi yang menyebabkan perubahan harga saham tersebut.

\section{Struktur Kepemilikan Saham}

Struktur kepemilikan (ownership structure) adalah komposisi kepemilikan dalam perusahaan yang mempengaruhi kinerja suatu perusahaan. Menurut Ramli (2014) struktur kepemilikan perusahaan adalah tingkat kepemilikan saham pihak tertentu (manajemen/institusional/publik) yang secara aktif ikut dalam pengambilan keputusan, diukur oleh proporsi saham yang akan dimiliki salah satu pihak tersebut pada akhir tahun dinyatakan dalam persen.

\section{Persentase Kepemilikan Publik}

Persentase kepemilikan saham publik menggambarkan tingkat kepemilikan perusahaan oleh masyarakat publik. Persentase kepemilikan saham publik ditunjukkan dengan persentase saham yang dimiliki masyarakat. Persentase tersebut dihitung dengan membandingkan saham yang dimiliki masyarakat dengan saham yang beredar. Semakin banyak saham yang dijual kepada masyarakat maka semakin besar saham yang beredar di masyarakat. Hal yang sama juga dinyatakan oleh Anisa (2011:29) dalam Ramli (2014) yang menyebutkan bahwa porsi saham publik menunjukan tingkat kepemilikan perusahaan oleh masyarakat publik, yaitu pihak individu yang berada di luar lingkar manajemen dan tidak memiliki hubungan istimewa dengannya. 
Kerangka Konseptual Penelitian

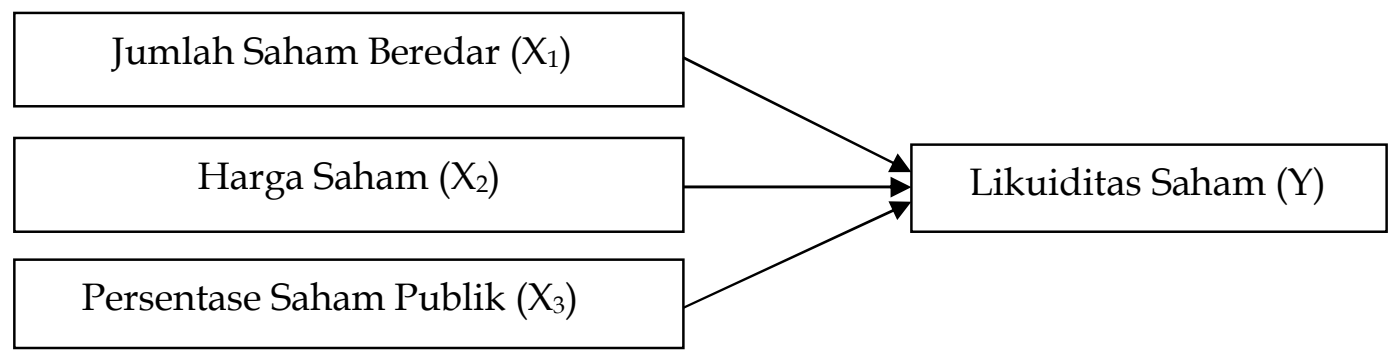

Hipotesis

Berdasarkan landasan teori, tinjauan penelitian terdahulu, maka dapat dirumuskan hipotesis penelitian sebagai berikut :

$\mathrm{H}_{1}$ : Diduga jumlah saham beredar berpengaruh positif dan signifikan terhadap likuiditas saham perusahaan.

$\mathrm{H}_{2}$ : Diduga harga saham berpengaruh negatif dan signifikan terhadap likuiditas saham perusahaan.

$\mathrm{H}_{3}$ : Diduga persentase saham publik berpengaruh positif dan signifikan terhadap likuiditas saham perusahaan.

\section{METODE PENELITIAN}

\section{Jenis Penelitian}

Jenis penelitian ini adalah penelitian asosiatif. Penelitian asosiatif merupakan penelitian yang bertujuan untuk mengetahui hubungan antara dua variabel atau lebih (Sugiyono, 2014).

\section{Populasi dan Sampel Penelitian}

\section{a. Populasi}

Berdasarkan data dari IDX, perusahaan sub sektor industri makanan dan minuman yang terdaftar di BEI periode 2010-2015 berjumlah 14 perusahaan.

b. Sampel

Teknik pengambilan sampel dalam penelitian ini menggunakan teknik Purposive sampling. Menurut Sugiyono (2014) teknik Purposive sampling merupakan teknik pengambilan sampel yang didasarkan pada beberapa pertimbangan atau kriteria tertentu. Kriteria perusahaan yang akan menjadi sampel dalam penelitian ini adalah :

1. Perusahaan yang sahamnya aktif diperdagangan selama periode triwulan I 2010 hingga triwulan IV Desember 2015.

2. Perusahaan yang menyediakan informasi mengenai jumlah saham beredar, harga saham, persentase saham publik dan frekuensi perdagangan saham selama periode triwulan I 2010 hingga triwulan IV Desember 2015.

Tabel 3. Daftar Nama Perusahaan Sebagai Sampel Penelitian

\begin{tabular}{|c|l|l|}
\hline No & Kode Perusahaan & \multicolumn{1}{c|}{ Nama Perusahaan } \\
\hline 1 & AISA & PT Tiga Pilar Sejahtera Tbk \\
\hline 2 & CEKA & PT Wilmar Cahaya Tbk \\
\hline 3 & DLTA & PT Delta Djakarta Tbk \\
\hline
\end{tabular}




\begin{tabular}{|c|l|l|}
\hline No & Kode Perusahaan & \multicolumn{1}{c|}{ Nama Perusahaan } \\
\hline 4 & ICBP & PT Indofood CBP Sukses Makmur Tbk \\
\hline 5 & INDF & PT Indofood Sukses Makmur \\
\hline 6 & MLBI & PT Multi Bintang Indonesia Tbk \\
\hline 7 & MYOR & PT Mayora Indah Tbk \\
\hline 8 & ROTI & PT Nippon Indosari Corporindo Tbk \\
\hline 9 & SKLT & PT Sekar Laut Tbk \\
\hline 10 & STTP & PT Siantar Top Tbk \\
\hline
\end{tabular}

Sumber : Indonesian Stock Exchange (IDX) Periode 2010-2015

\section{Metode Pengumpulan Data}

Metode pengumpulan data yang digunakan adalah sample survey. Menurut Arikunto (2010) survey merupakan cara mengumpulkan data dari sejumlah unit atau individu dalam waktu atau jangka waktu yang bersamaan. Survey yang dimaksud dalam penelitian ini bukan survey lapangan, akan tetapi survey pustaka dengan pengumpulan data dari buku, catatan-catatan atau dokumen berupa jurnal-jural atau berbagai bentuk terbitan periodik seperti laporan-laporan dan referensi lainnya yang berkaitan dengan masalah yang diteliti.

\section{Prosedur Analisis Data}

\section{Analisis Statistik Deskriptif}

Statistik deskriptif digunakan untuk menggambarkan suatu data secara statistik. Statistik deskriptif dalam penelitian ini merujuk pada nilai rata-rata (mean) dan simpanan baku (standard deviation), nilai minimum dan maksimum dari seluruh variabel dalam penelitian ini.

\section{Uji Asumsi Klasik}

Uji asumsi klasik bertujuan untuk mengetahui apakah penaksir dalam regresi merupakan penaksir kolinier tak bias terbaik. Untuk memperoleh persamaan yang paling tepat digunakan parameter regresi yang dicari dengan metode kuadrat terkecil atau Ordinary Least Square (OLS). Uji asumsi klasik dalam penelitian ini terdiri dari uji normalitas, uji multikolinieritas, uji heteroskedastisitas dan uji autokorelasi.

\section{Analisis Regresi Linier Berganda}

Ghozali (2012) menyatakan analisis regresi linier berganda digunakan untuk menganalisis variabel terikat dengan lebih dari satu variable bebas. Perhitungan regresi linier berganda dengan bantuan program SPSS Versi 22.00 for windows. Model regresi linier berganda dalam penelitian ini dapat dirumuskan sebagai berikut:

$$
\begin{aligned}
& \mathrm{Y}=\alpha_{0}+\beta_{1} \mathrm{X}_{1}+\beta_{2} \mathrm{X}_{2}+\beta_{3} \mathrm{X}_{3}+\mathrm{e} \\
& \text { dimana dalam penelitian ini : } \\
& \mathrm{Y}=\text { Likuiditas saham (Frekuensi perdagangan saham) } \\
& \mathrm{X}_{1}=\text { Jumlah saham beredar } \\
& \mathrm{X}_{2}=\text { Harga saham } \\
& \mathrm{X}_{3}=\text { Persentase saham publik } \\
& \alpha_{0}=\text { Konstanta } \\
& \beta_{1}=\text { Koefisien regresi variabel jumlah saham beredar } \\
& \beta_{2}=\text { Koefisien regresi harga saham } \\
& \beta_{3}=\text { Koefisien regresi persentase saham publik }
\end{aligned}
$$




\section{Uji t (Uji Parsial)}

$$
\text { e }=\text { Term of error }
$$

Uji t digunakan untuk melihat apakah secara parsial variabel bebas berpengaruh signifikan terhadap variabel terikat. Ghozali (2012) menyatakan langkah-langkah pengujian uji $t$ adalah sebagai berikut:

a. Merumuskan hipotesis statistik

$\mathrm{H}_{0}: \mathrm{b}_{\mathrm{i}}=0$, berarti tidak terdapat pengaruh yang signifikan secara parsial dari variabel bebas terhadap variabel terikat.

$\mathrm{H}_{\mathrm{a}}: \mathrm{b}_{\mathrm{i}} \neq 0$, berarti terdapat pengaruh yang signifikan secara parsial dari variabel bebas terhadap variabel terikat.

b. Menentukan Level of significance $(\alpha)$ sebesar $5 \%$.

c. Mengambil keputusan berdasarkan nilai signifikan t hasil perhitungan, yaitu:

- Jika nilai signifikan $\mathrm{t}>0,05$, maka $\mathrm{H}_{0}$ gagal ditolak.

- Jika nilai signifikan $\mathrm{t}<0,05$, maka $\mathrm{H}_{0}$ ditolak.

\section{HASIL DAN PEMBAHASAN}

\section{Hasil Uji Asumsi Klasik}

Berdasarkan hasil pengolahan data diketahui bahwa data dalam penelitian ini terdistribusi normal. Hasil uji Kolmogorov-Smirnov menunjukkan bahwa variabel jumlah saham beredar, harga saham, persentase saham publik dan likuiditas saham memiliki nilai signifikansi Asymp Sig (2 tailed) yakni 0,051 > 0,05. Hasil uji mutikolinieritas menunjukkan bahwa nilai VIF semua variabel kurang dari 10 dimana nilai VIF masing-masing variabel independen yaitu jumlah saham beredar sebesar 1,183, harga saham sebesar 1,100 dan persentase saham publik sebesar 1,133. Kemudian nilai tolerance ketiga variabel juga di atas 0,1 . Berdasarkan hasil tersebut maka dapat disimpulkan bahwa antar variabel independen bebas multikolinieritas.

Hasil uji heterokedastisitas menggunakan metode Spearman Correlation menunjukkan bahwa nilai korelasi ketiga variabel independen dengan Unstandardized Residual memiliki nilai signifikansi lebih besar dari 0,05 yakni 0,355 untuk jumlah saham beredar, nilai korelasi sebesar 0,470 untuk harga saham dan 0,282 untuk persentase saham publik. Karena signifikansi ketiga variabel lebih dari 0,05 maka dapat disimpulkan bahwa tidak terjadi masalah heterokedastisitas. Terakhir, hasil uji autokorelasi menunjukkan bahwa nilai dw sebesar 1,905 lebih besar dari batas atas du sebesar 1,68891 yang berarti bahwa nilai dw berada di antara $\mathrm{du}<\mathrm{dw}<4$-du, sehingga dapat disimpulkan bahwa tidak terdapat autokorelasi pada model regresi.

\section{Hasil Analisis Regresi Linier Berganda}

Setelah dilakukan pengolahan data dengan menggunakan program SPSS Versi 22.00 for windows diperoleh hasil regresi linier berganda sebagai berikut:

Tabel 4. Data Unstandardized Coefficients Beta, Standardized Coefficients Beta, $\mathrm{t}$ hitung dan Tingkat Signifikansi Coefficients ${ }^{\mathrm{a}}$

\begin{tabular}{|l|l|c|c|c|c|c|}
\hline \multirow{2}{*}{\multicolumn{2}{c}{ Model }} & \multicolumn{2}{|c|}{ Unstandardized Coefficients } & $\begin{array}{c}\text { Standardized } \\
\text { Coefficients }\end{array}$ & $\mathrm{t}$ & Sig. \\
\cline { 3 - 7 } & B & Std. Error & Beta & & \\
\hline 1 & (Constant) & -1337.761 & 997.520 & & -1.341 & .185 \\
\hline
\end{tabular}




\begin{tabular}{|l|l|r|r|r|r|r|}
\hline & Jumlah_saham_beredar & $3.876 \mathrm{E}-6$ & .000 & .831 & 9.798 & .000 \\
\cline { 2 - 6 } & Harga_saham & .003 & .004 & .062 & .786 & .435 \\
\hline & Persentase_saham_publik & 16.346 & 52.919 & .025 & .309 & .759 \\
\hline
\end{tabular}

a. Predictors : persentase_saham_publik, harga_saham, jumlah_saham_beredar

b. Dependent Variable : likuiditas_saham

Sumber : Output SPSS

Berdasarkan tabel 4 di atas, maka dapat disusun persamaan regresinya sebagai berikut :

$$
\mathrm{Y}=-1337,7+3.876 \mathrm{E}-6 \mathrm{X}_{1}+0,003 \mathrm{X}_{2}+16.346 \mathrm{X}_{3}
$$

Berdasarkan persamaan di atas maka dapat diinterpretasikan sebagai berikut :

a. Nilai konstanta $\alpha$ sebesar $-1337,761$ artinya jika variabel jumlah saham beredar, harga saham dan persentase saham publik bernilai nol atau tidak ada nilainya, maka likuiditas saham memiliki nilai -1337,761 atau akan turun sebesar 1337,761 kali. Dengan kata lain, ada pengaruh variabel-variabel lain di luar jumlah saham beredar, harga saham dan persentase saham publik yang mempengaruhi likuiditas saham sebesar -1337,761 kali.

b. Besarnya koefisien untuk variabel jumlah saham beredar sebesar 3.876E-6 satuan dengan arah koefisien positif. Hal ini menunjukkan bahwa jika nilai jumlah saham beredar meningkat sebesar 1 lembar saham maka akan menyebabkan likuiditas saham meningkat sebesar 3.876E-6 kali.

c. Besarnya koefisien untuk variabel harga saham sebesar 0,003 satuan dengan arah koefisien positif. Hal ini berarti bahwa jika harga saham meningkat sebesar 1 rupiah maka akan menyebabkan likuiditas saham meningkat sebesar 0,003 kali.

d. Besarnya koefisen untuk variabel persentase saham publik sebesar 16.346 satuan dengan arah koefisien positif. Hal ini berarti bahwa jika persentase saham publik meningkat sebesar 1 persen maka likuiditas saham akan meningkat sebesar 16.346 kali.

\section{Hasil Uji t (Uji Parsial)}

a. Hipotesis $1\left(\mathrm{H}_{1}\right)$ : thitung untuk jumlah saham beredar sebesar 9,798 $>t_{\text {tabel }}$ yaitu 2,705 maka $\mathrm{H}_{\mathrm{a}}$ diterima. Pada nilai signifikasi, jumlah saham beredar memiliki nilai sig yang lebih kecil dari $(\alpha)$ yaitu $0,000<0,05$. Dengan demikian, dapat disimpulkan bahwa jumlah saham beredar berpengaruh positif dan signifikan terhadap likuiditas saham.

b. Hipotesis $2\left(\mathrm{H}_{2}\right)$ : thitung untuk harga saham sebesar $0,786<\mathrm{t}_{\text {tabel }}$ yaitu 2,705 maka $\mathrm{H}_{0}$ diterima. Pada nilai signifikasi, harga saham memiliki nilai sig yang lebih besar dari ( $\alpha$ ) yaitu $0,435>0,05$. Berdasarkan hasil tersebut maka dapat disimpulkan bahwa harga saham berpengaruh positif tetapi tidak signifikan terhadap likuiditas saham.

c. Hipotesis $3\left(\mathrm{H}_{3}\right)$ : thitung untuk persentase saham publik sebesar $0,309<\mathrm{t}_{\text {tabel }}$ yaitu 2,705 maka $\mathrm{H}_{0}$ gagal ditolak. Pada nilai signifikasi, persentase saham publik memiliki nilai sig yang lebih besar dari $(\alpha)$ yaitu $0,759>0,05$. Berdasarkan hasil tersebut maka dapat disimpulkan bahwa persentase saham publik berpengaruh positif tetapi tidak signifikan terhadap likuiditas saham. 


\section{Koefisien Determinasi $\left(\mathrm{R}^{2}\right)$}

Untuk mengetahui besarnya pengaruh variabel bebas (Jumlah saham beredar, harga saham dan persentase saham publik) terhadap perubahan variabel terikat (Likuiditas saham) dapat diketahui dari nilai koefisien determinasi berganda (Adjusted $R^{2}$ ) sebagaimana disarikan pada tabel sebagai berikut:

Tabel 5 Hasil Koefisien Determinasi Model Summary

\begin{tabular}{|c|r|r|r|r|}
\hline Model & R & R Square & Adjusted R Square & Std. Error of the Estimate \\
\hline 1 & $.817^{\mathrm{a}}$ & .667 & .648 & 4840.43471 \\
\hline $\begin{array}{l}\text { a. Predictors: (Constant), persentase_saham_publik, harga_saham, jumlah_saham_beredar } \\
\text { b. Dependent Variable: likuiditas_saham }\end{array}$
\end{tabular}

Sumber : Output SPSS

Berdasarkan tabel 5 di atas diketahui nilai koefisien determinasi sebesar 0,648. Hal ini berarti bahwa 64,8\% likuiditas saham dapat dijelaskan oleh variabel-variabel independen yang masuk dalam model regresi yaitu jumlah saham beredar, harga saham dan persentase saham publik. Sedangkan sisanya yaitu 35,2\% dijelaskan oleh variabel lain yang tidak dimasukkan dalam model regresi.

\section{PEMBAHASAN}

\section{a. Pengaruh Jumlah Saham Beredar Terhadap Likuiditas Saham}

Secara parsial jumlah saham beredar berpengaruh positif dan signifikan terhadap likuiditas saham dengan koefisien regresi bernilai positif yang menunjukkan bahwa hubungannya dengan likuiditas saham searah (linier). Dengan demikian $\mathrm{H}_{1}$ dalam penelitian ini diterima (Accepted). Ketika jumlah saham beredar meningkat maka likuiditas saham juga akan meningkat. Salah satu alasan jumlah saham beredar berpengaruh positif dan signifikan adalah karena selama tahun pengamatan peningkatan jumlah saham beredar yang terjadi sangat tajam seperti yang ditunjukkan oleh perusahaan dengan kode MLBI yang menunjukkan peningkatan hingga mencapai 10.000 persen pada tahun 2014 dan diikuti pula dengan peningkatan rata-rata frekuensi perdagangan saham yang paling tinggi selama tahun pengamatan yaitu yang terjadi pada tahun 2014 sebesar 3.504 kali atau 51,94 persen. Hal ini didukung oleh temuan Ramli (2014), Mulyaningsih (2013) dan Elta (2016) bahwa jumlah saham beredar berpengaruh positif dan signifikan terhadap likuiditas saham. Jumlah saham beredar menentukan berapa banyak saham yang dapat dimiliki oleh para investor. Jumlah saham beredar juga dapat mempengaruhi minat dan daya beli investor. Jika jumlah saham beredar besar maka akan membuka peluang untuk calon investor berinvestasi pada saham tersebut, sehingga dapat menarik minat dan meningkatkan daya beli para investor sehingga likuiditas saham akan meningkat (Ramli, 2014). Jika jumlah saham beredar kecil akan sulit mengantisipasi peningkatan minat beli investor, sehingga investor akan beralih ke saham perusahaan lain.

Ramli (2014) menjelaskan bahwa unsur jumlah saham beredar akan menunjukkan kondisi emiten penerbit saham. Nilai ini memberi sinyal bagi investor 
terkait prospek investasinya di masa mendatang. Meski kinerja perusahaan baik, tapi jumlah saham beredarnya kecil, dapat mengakibatkan saham tersebut sulit untuk dimiliki dan akan menurunkan likuiditas saham.

\section{b. Pengaruh Harga Saham Terhadap Likuiditas Saham}

Secara parsial menunjukkan bahwa harga saham berpengaruh positif tetapi tidak signifikan terhadap likuiditas saham. Temuan tersebut sejalan dengan hasil penelitian Hadya (2013) yang menyatakan bahwa harga saham berpengaruh positif tetapi tidak signifikan terhadap likuiditas saham. Hal ini berarti $\mathrm{H}_{2}$ dalam penelitian ini yang menyatakan bahwa harga saham berpengaruh negatif dan signifikan terhadap likuiditas saham ditolak (Rejected). Harga saham berpengaruh positif tetapi tidak signifikan karena menurut Jogiyanto (2013) bahwa semakin tinggi harga saham, maka semakin tinggi pula nilai perusahaan dimana mengingat bahwa harga saham merupakan salah satu indikator keberhasilan pengelolaan perusahaan tersebut. Semakin baik prestasi perusahaan dalam menghasilkan suatu keuntungan, maka akan meningkatkan permintaan saham perusahaan tersebut, sehingga akan meningkatkan harga saham itu sendiri. Oleh karena itu, hipotesis yang menyatakan bahwa harga saham berpengaruh negatif terhadap likuiditas saham tidak diterima karena ternyata investor tidak terlalu tertarik pada harga saham yang rendah dan daya beli saham yang mereka miliki akan tetapi lebih tertarik dengan harga saham yang tinggi karena mencerminkan nilai dan kinerja perusahaan yang baik. Mengingat bahwa semakin tinggi harga saham maka semakin tinggi pula nilai perusahaan dan semakin baik prestasi perusahaan dalam menghasilkan suatu keuntungan. Namun demikian, apabila harga saham dinilai terlalu tinggi (Overvalued), maka dapat mengurangi minat dan daya beli investor untuk berinvestasi sehingga harga saham sulit meningkat lagi (Jogiyanto, 1998). Minat beli investor tercermin dari tinggi atau rendahnya likuiditas saham. Begitu juga apabila harga saham dianggap terlalu rendah (Undervalued), maka calon investor menilai bahwa harga tersebut mencerminkan kinerja dan prestasi perusahaan yang kurang baik sehingga menurunkan likuiditas saham.

Di bursa saham terdapat banyak sekali calon pembeli dan penjual saham (emiten). Oleh karenanya, persepsi masing-masing pelaku pasar mengenai harga suatu saham tentu akan berbeda-beda. Terkadang harga yang ditawarkan oleh penjual terasa terlalu mahal (Overprice), terkadang malah terlihat terlalu murah (Underprice). Hal tersebutlah yang menjadikan harga saham menjadi sangat fluktuatif. Harga pasar yang wajar merupakan harga yang mencerminkan nilai perusahaan yang sebenarnya. Harga pasar yang wajar ini akan mempengaruhi minat beli investor dan likuiditas sebuah saham.

Hal penting yang perlu diperhatikan dalam menilai harga suatu saham wajar atau tidak telah dijelaskan oleh Widoadmodjo (1996) dalam Hadya (2013) yaitu yang pertama, terkait bagaimana potensi laba di masa yang akan datang (potensial earnings) dimana tercermin dalam proyeksi kondisi keuangan perusahaan. Jika proyeksi menunjukkan laba yang besar maka investor dapat bersedia menerima harga yang tinggi. Kedua, nilai aktiva netto (net asset value) yang merupakan nilai seluruh aktiva yang dimiliki perusahaan, yang didasarkan pada hasil penilaian terakhir (bukan nilai buku) dikurangi dengan nilai seluruh kewajiban perusahaan baik yang ada maupun yang timbul di kemudian hari. Apabila nilai aktiva netto besar maka perusahaan dapat menetapkan harga yang tinggi dan calon investor tentunya bersedia menerima harga tersebut. Ketiga, kemampuan membayar dividen (dividend 
paying capacity) di masa lampau dan di masa yang akan datang. Hal ini menyangkut berapa lama perusahaan telah membayar dividen, berapa besarnya dan bagaimana kebijaksanaannya di masa yang akan datang. Jika dividen yang dibayarkan pada calon investor besar dan kebijaksanaannya dalam menetapkan dividen dapat menguntungkan para investor, maka para investor akan bersedia menerima harga yang tinggi, demikian sebaliknya. Keempat, perbandingan harga saham industri sejenis dimana apabila suatu perusahaan baru pertama kali mengadakan emisi saham dan perusahaan belum begitu terkenal di masyarakat, maka sebaiknya harga yang ditetapkan lebih rendah dari harga saham perusahaan sejenis yang telah terlebih dahulu melakukan go public.

Oleh karena itulah alasan bahwa harga saham berpengaruh positif tetapi tidak signifikan yaitu karena harga saham yang tinggi memang menggambarkan prospek dan kinerja yang baik dari perusahaan tersebut. Akan tetapi apabila didasarkan dari metode penilaian yang telah dijelaskan sebelumnya harga saham dinilai terlalu tinggi, maka akan mengurangi minat dan daya beli para investor dan akan berpengaruh pada likuiditas saham tersebut.

\section{c. Pengaruh Persentase Saham Publik Terhadap Likuiditas Saham}

Hasil uji t menunjukkan bahwa persentase saham publik berpengaruh positif tetapi tidak signifikan terhadap likuiditas saham. Hal ini berarti $\mathrm{H}_{3}$ yang menyatakan bahwa persentase saham publik berpengaruh positif dan signifikan terhadap likuiditas saham ditolak (Rejected). Persentase saham publik berpengaruh positif dan tidak signifikan ini diperkuat oleh hasil penelitian Ramli (2014) yang menyatakan bahwa jika tinggi rendahnya persentase saham publik memberi informasi bagi setiap investor terutama berkaitan dengan besarnya return yang akan dia terima jika turut berinvestasi di saham tersebut. Semakin besar proporsi kepemilikan saham oleh publik, maka semakin banyak pihak yang membutuhkan informasi tentang perusahaan sehingga semakin menumbuhkan kepercayaan publik kepada perusahaan tersebut semakin besar.

Persentase saham publik juga mempengaruhi ekspektasi dan kebijakan investasi bagi seorang investor. Hal ini dikarenakan seorang investor saham memiliki hak dan wewenang terbatas sesuai dengan jumlah saham yang dia miliki. Apabila persentase saham publik tinggi maka wewenang yang dimiliki para investor terhadap kelangsungan hidup dan pengawasan perusahaan juga akan meningkat sehingga membuat para investor merespon positif tingginya persentase saham publik tersebut (Erlinawati dan Mawardi, 2013). Namun demikian, pengaruh persentase saham publik yang positif tidak signifikan terhadap likuiditas saham ini dapat disebabkan karena selama periode pengamatan rata-rata perubahan persentase saham publik setiap tahunnya tidak mengalami peningkatan maupun penurunan yang tajam dan signifikan, melainkan stabil dan bahkan ada yang tetap selama 3 tahun atau lebih. Oleh karena itu, persentase saham publik tidak memberikan pengaruh yang signifikan terhadap likuiditas saham.

d. Variabel Dominan yang Mempengaruhi Likuiditas Saham

Berdasarkan hasil analisis regresi linier berganda pada tabel Standardized coefficient menunjukkan bahwa variabel jumlah saham beredar memiliki nilai beta positif terbesar yaitu sebesar 0,831 dibandingkan variabel harga saham dan persentase saham publik yang memiliki nilai masing-masing yaitu sebesar 0,062 dan 0,025 . Hal ini berarti variabel jumlah saham beredar memiliki pengaruh dominan terhadap likuiditas saham. Jumlah saham beredar memiliki pengaruh yang dominan 
terhadap likuiditas saham karena jumlah saham beredar menentukan berapa banyak saham yang dapat dimiliki oleh para investor. Jika jumlah saham beredar besar, maka akan membuka peluang untuk calon investor berinvestasi pada saham tersebut yang dapat menarik minat dan meningkatkan daya beli para investor sehingga meningkatkan likuiditas saham (Ramli, 2014). Hal ini diperkuat oleh Reilly dan Brown (2003) dalam Erlinawati dan Mawardi (2015) bahwa likuiditas saham bisa ditentukan dari besarnya volume perdagangan saham yang bisa diukur melalui jumlah saham beredar ataupun nilai dari transaksi yang dilakukan.

\section{KESIMPULAN DAN SARAN}

\section{Kesimpulan}

Berdasarkan hasil analisis data dan pembahasan yang telah dipaparkan sebelumnya, maka kesimpulan dalam penelitian ini adalah sebagai berikut:

1. Hasil uji t menunjukkan bahwa hanya variabel jumlah saham beredar yang memiliki pengaruh positif dan signifikan terhadap likuiditas saham. Sedangkan harga saham dan persentase saham publik berpengaruh positif tetapi tidak signifikan terhadap likuiditas saham.

2. Berdasarkan nilai adjusted $R$ square sebesar 0,648, menunjukkan bahwa jumlah saham beredar, harga saham dan persentase saham publik mampu menjelaskan likuiditas saham sebesar 64,8 persen dan sisanya sebesar 35,2 persen dijelaskan oleh variabel lain di luar model dalam penelitian ini.

3. Jumlah saham beredar merupakan variabel yang memiliki pengaruh dominan terhadap likuiditas saham, hal ini ditunjukkan oleh nilai Standardized beta

\section{Saran} coefficient sebesar 0,831 .

1. Bagi Perusahaan

Pertama, diharapkan agar mampu memberikan peluang kepada para investor untuk berinvestasi dengan tetap menjaga jumlah saham beredar dan persentase saham publik yang ditetapkan untuk menarik minat dan daya beli investor. Mengingat jumlah saham beredar memiliki pengaruh yang signifikan terhadap likuiditas saham maka perusahaan perlu membuka lebar kesempatan berinvestasi kepada masyarakat luas dengan menyediakan jumlah saham beredar yang besar apabila ingin likuiditas saham perusahaan tersebut terus meningkat. Kedua, diharapkan agar mampu menetapkan harga saham yang wajar dimana tidak terlalu tinggi (overvalued) dan tidak terlalu rendah (undervalued) mengingat banyaknya karakteristik penilaian yang dilakukan oleh calon investor. Sehingga perusahaan harus melakukan penentuan harga yang tepat dan realistis agar memenuhi kriteria penilaian harga saham yang wajar, dapat diterima dan dapat membentuk perspektif yang positif dari para investor yang akan berinvestasi pada saham perusahaan tersebut.

2. Bagi Investor

Penelitian ini diharapkan mampu dijadikan sebagai acuan, referensi dan bahan pertimbangan untuk melihat kondisi perusahaan sub sektor makanan dan minuman khususnya terkait dengan kondisi likuiditas saham serta faktor - faktor yang mempengaruhi likuiditas saham seperti jumlah saham beredar, harga saham dan persentase saham publik sehingga dapat membuat keputusan-keputusan dalam berinvestasi di Bursa Efek Indonesia. 
3. Bagi Peneliti Selanjutnya

Diharapkan dapat meneliti faktor-faktor lain di luar variabel yang diteliti dalam penelitian ini untuk menghindari dampak sampel bias. Selain itu, juga dapat memperpanjang periode pengamatan dan disarankan untuk memperluas cakupan penelitian dengan sampel perusahaan yang lebih besar.

\section{DAFTAR PUSTAKA}

Adriana, Rina. 2007. Pengaruh Stock Split terhadap Likuiditas dan Return Saham di Bursa Efek Jakarta. Skripsi : Universitas Negeri Padang.

Arikunto, S. 2010. Suatu Pendekatan Praktik (Edisi Revisi). Rineka Cipta, Jakarta.

Brigham, Eugene F dan Joel F. Houston. 2010. Dasar-Dasar Manajemen Keuangan (Essentials of Financial Management). Buku 1. Salemba Empat, Jakarta.

Carolina, Agnes. 2014. Analisis Pengaruh Mekanisme Tata Kelola Perusahaan dan Manajemen Laba Terhadap Likuiditas Pasar Saham. Skripsi: Fakultas Ekonomi dan Bisnis Universitas Diponegoro.

Elta, Ledina. 2016. Pengaruh Jumlah Saham Beredar, IFR, Tingkat Pengungkapan Informasi Website dan Harga Saham Penutupan Terhadap Frekuensi Perdagangan Saham Perusahaan (Studi Pada Perusahaan Yang Terdapat Pada Indeks Kompas100 Februari-Juli 2015). Skripsi: Fakultas Ekonomi dan Bisnis Universitas Diponegoro.

Erlinawati, Ira dan Mawardi, Imron. 2015. Pengaruh Jumlah Saham Beredar, Harga Saham, dan Persentase Saham Publik Terhadap Likuiditas Perusahaan yang Listing di JII Periode 2013. Jurnal Ekonomi dan Bisnis, Vol. 2, No. 2; hlm. 130-146.

Ghozali, Imam. 2012. Aplikasi Analisis Multivariate Dengan Program SPSS. BP Undip, Semarang.

Hadya, Rizka. 2013. Pengaruh Harga dan Risiko Saham Terhadap Likuiditas Saham Pada Perusahaan-Perusahaan Yang Terdaftar Di Bursa Efek Indonesia. Jurnal KBP, Vol. 1, No. 2; hlm. 208-231.

Jogiyanto, Hartono. 2013. Teori Portofolio dan Analisis Investasi. BPFE, Yogyakarta.

Mubarokah, Farid 2011. Analisis Pengaruh Harga Saham, Return Saham, dan Volume Perdagangan Terhadap Likuiditas Saham Pada Perusahaan Go Public Yang Melakukan Stock Split Di Bursa Efek Indonesia Periode Januari 2007 Sampai Dengan Maret 2011. Skripsi: Fakultas Ekonomi Universitas Negeri Semarang.

Mulyana, Deden. 2011. Analisis Likuiditas Saham serta Pengaruhnya Terhadap Harga Saham Pada Perusahaan yang Berada Pada Indeks LQ45 di Bursa Efek Indonesia. Jurnal Manajemen, Vol. 4, No. 1; hlm. 77-96.

Mulyaningsih, Ayu. 2013. Analisis Pengaruh Jumlah Saham Beredar, Arus Kas, dan Rasio Profitabilitas Terhadap Likuiditas Saham Pada Perusahaan Otomotif yang Terdaftar Di Bursa Efek Indonesia. Jurnal Psikologi, Ekonomi, Sastra, dan Teknik Sipil, Vol. 5; hlm. 1858-2559.

Pane. 2016. Analisis Pengaruh Faktor-Faktor Makro Ekonomi dan Kinerja Keuangan Terhadap Nilai Perusahaan Sektor Industri Makanan dan Minuman yang Listed di BEI. Skripsi : Fakultas Ekonomi Universitas Sumatera Utara.

Rahma, Qonita Aulia. 2015. Analisis Pengaruh Harga Saham, dan Volume Perdagangan Terhadap Likuiditas Saham Pada Perusahaan Go Public yang Melakukan Stock Split di Bursa Efek Indonesia Pada Periode 2013-2014. Skripsi: 
Fakultas Ekonomi Universitas Islam Maulana Malik Ibrahim.

Ramli, Rahmayani. 2014. Faktor-Faktor yang Mempengaruhi Tingkat Likuiditas Saham

Pada Perusahaan LQ45 Yang Listing di BEI. Thesis : Universitas Islam Negeri

Riau Sultan Syarif Kasim Riau.

Samsul, Mohamad. 2006. Pasar Modal dan Manajemen Portofolio. Erlangga, Surabaya.

Sari, Debi Permata. 2013. Pengaruh Implementasi IFRS Dalam Indeks Gray: Leverage,

Likuiditas, Profitabilitas, dan Porsi Saham Publik Terhadap Pengungkapan

Laporan Keuangan. Skripsi : Fakultas Ekonomi Universitas Negeri Semarang.

Sedyati, Pipit Wahyu 2010. Analisis Pengaruh Harga Saham dan Volume

Perdagangan Terhadap Likuiditas Saham Pada Perusahaan Manufaktur Go

Public yang Melakukan Stock Split di Bursa Efek Indonesia. Skripsi : Fakultas

Ekonomi UPN Veteran.

Silviyani, Ni Luh Nonik Tika., Sujana, Edy dan Made Pradana Adiputra. 2014.

Pengaruh Likuiditas Perdagangan Saham dan Kapitalisasi Pasar Terhadap Return

Saham Perusahaan yang Berada Pada Indeks LQ45 di BEI Periode Tahun 2009-

2013 (Studi Empiris Pada Perusahaan LQ45 di BEI), Jurnal Akuntansi, Vol. 2, No. 1.

Sudana, I Made dan Intan, Nurul. 2008. Leverage Keuangan dan Likuiditas Saham

Perusahaan Manufaktur yang Terdaftar di Bursa Efek Jakarta. Jurnal

Manajemen Teori dan Terapan, Vol. 1, No. 3; hlm, 127-143.

Sugiyono. 2014. Metode Penelitian Bisnis. Alfabeta, Bandung.

Suriyani, Putu Putri.,Yuniarta, Gede Adi dan Ananta Wikrama T.A. 2015. FaktorFaktor yang Mempengaruhi Manajemen Laba (Studi Empiris Pada Perusahaan Manufaktur yang Terdaftar di BEI Periode Tahun 2008-2013), Jurnal Akuntansi, Vol. 3, No. 1.

Widowati, Cici. 2013. Pengaruh Harga, Volatilitas Return, dan Volume Transaksi Saham Terhadap Likuiditas Saham, Jurnal Bisnis dan Manajemen, Vol. 1, No. 1; hlm. 26-55.

Wira, Varieyatmi. 2013. Analisis Dampak Rasio Keuangan Terhadap Likuiditas Saham Pada Industri Otomotif di Bursa Efek Indonesia, Jurnal Manajemen dan Kewirausahaan, Vol. 4, No. 1; hlm. 503-2086. 